\title{
Employee Performance Appraisal in Business
}

\author{
Mohammad Ghozali ${ }^{1}$, Hamid Fahmy Zarkasyi ${ }^{2}$, Kurnia Firmanda Jayanti ${ }^{3}$, Yunita \\ Wulandari ${ }^{4}$ \\ \{ohammadghozali@unida.gontor.ac.id¹, hfzark@unida.gontor.ac.id², \\ kurniafirmanda@unida.gontor.ac.id ${ }^{3}$, yunita.wulan@unida.gontor.ac.id $\left.{ }^{4}\right\}$ \\ ${ }^{1,2,3,4}$ University of Darussalam Gontor, Jl.Raya Siman Km.6 Siman, Ponorogo, East Java 63471 \\ Indonesia
}

\begin{abstract}
This study aims to analyze employee performance appraisal that success concepts can be formed in business or entrepreneurship. Performance appraisal can be called as a performance which is a form of behavior carried out on what has been achieved by employees in a given role in a company. Employee performance is one of the human resources to achieve the goals of a company or entrepreneurial business. The method used is a qualitative method with three methods of data collection, they are observation, interview, and documentation. This research shows that employee performance appraisal is very necessary for a company, business or entrepreneurial organization. Performance appraisal can spur the success of a business in a company.
\end{abstract}

Keywords: Performance Appraisal, Business, Human Reseach Development, Employee

\section{Introduction}

The success level of a program or activity can not be separated from the ability of humans who process it, but it is also important to pay attention to the personal ethical issues concerned. Success in a business is also influenced by behaviors and ethics in working or doing business. In surah Ar-Rohman verse 33, Allah has encouraged humans to seek knowledge as far as possible without any limitation in order to prove the omnipotence of Allah SWT. [1] So, humans must use their knowledge to improve their quality. Because the key to the well-being of human life lies in the attitude and action that they do.

In the scope of companies or businesses that have employees to help achieving the company or business goals, the employee performance also contributes to this.Employee performance appraisal is an indicator to determine the quality of human resource in an organization. Properly designed and realizing the process of employee's appraisal is not only the necessary basis of successful employee performance management, but also provides valuable information for other human resource management functions.[2]

Therefore, performance appraisal models need to be understood and noticed in related companies or businesses. In addition, the ethics or personality of each employee in fitting their duties and functions in a company or business also need to be understood.

\section{Performance Appraisal Assessment}

Based on Ibn Khaldun's thoughts on the theory of value, the value of something lies in the human work that is poured out on him. In other words, the substance of value is working.[3] By working too, someone can fulfill their life needs. Working is not a movement without 
conscious thought, but working is a dynamic and creative self-totality movement as a choice.[4] This choice must be made in human life as a way to meet their daily need.

A job must have a clear explanation of the duties and obligations of each job. Here is the job description, a job description is simply a clear, concise depiction of a job's duties and requirements.[5] This is to align the employee performance appraisal with the duties and obligations obtained.

According to Sunyoto, performance appraisal is an embodiment of someone in carrying out work. It is said that they have achieved well if they can carry out their work well, it means that they reach the target with the specified standard. Performance appraisal according to Mathis and Jackson is a process of evaluating employee performance in doing their work compared to a set of standards, and then communicating it with employees. [6]

Performance criteria will need to be included where job descriptions are being used to define targets as part of a performance management process. Job performance is direcly related to the level of energy and the specific form of action characterizing a worker's energy and appropriate shapes behavioral patterns, it plays a key role in determining overall job performance.[7] Besides that,motivating employeesworkcan also improve the performance of employees in the company or business.

Spuck, following Katz and Kahn, elaborated the concept of working motivation to include; three major classifications of behavior required for organizational functioning and effectiveness: joining and staying in the system (recruitment, absenteeism, and turnover), dependable behavior/ role performance in the system (meeting or exceeding quantitative and qualitative standards of performance), and innovative and spontaneous behavior, Performance beyond role requirements (creativity, self-training, creating favorable climate, protecting the system, and cooperation).[8]

The performance appraisal method is basically carried out to determine the extent of the success of employees in carrying out the tasks they carry. Siagian stated that the employee performance appraisal methods are as follows:[9]

1. Past performance appraisal methods

In general, this method has a goal or objective to assess the job performance of employees objectively for a certain period of time in the past whichthe results are good for the organization, such as for the benefit of employee mutation, as well as for the employee concerned himself in the period of career development. The methods of past performance appraisal are Rating Scale, Checklist, Critical Incident Method, Field Review Method, Test and Observation of Job Performance, Group Evaluation Method (Ranking, Grading or Forced Distributions, Point Allocation Method).

2. Future-oriented performance appraisal methods In general, this method has a goal or objective in predicting the potential of the employee being assessed so that he can realistically determine his career plan and choose the development technique that is most suitable for him. Future-oriented performance appraisal methods are Self-Appraisals, Management by Objectives (MBO) Approaches, and Assessment Center Techniques.

Rating Scales consists of several numerical scales representing job-related performance criteria such as dependability, attendance, output, initiative, attitude, etc. Each scales ranges are formed from excellent to poor and the total numerical scores are computed and final conclusions are removed. 
Checklist, by this methodthe HR department, prepared the list of a statement in the form of Yes or No based question of traits of employee. Then, the appraisal system of an employee is done by reporting or checking the prepared question.[10]

Critical Incident Method according to Flanagan as a set of procedures designed to describe human behavior by collecting description of events having special significance and meeting systematically. For this, he originally used trained observers to collect critical incident identification. Identification of the critical incident during task performance can be an individual process or a mutual process between user and evaluator.[2]

Self Appraisals, according to Heery and Noon, self-appraisal is the technique of evaluating your own performance and then discussing this with your line manager. Selfappraisal is useful when managers seek to increase an employee's involvement in the performance appraisal process.[11] Self-appraisal has an important role to play inthe employee development.[12]

Management by Objectives, in 1954, "Management by Objective" was introduced by Peter F. Drucker in his book"The Practice of Management". It comprises of three building block, they are object formulation, execution process, and performance feedback. Weihrich In 2000, suggested a new model: the system approach to MBO (SAMBO). SAMBO comprises seven elements, they are strategic planning and hierarchy of objects, setting objectives, planning for action, implementation of $\mathrm{MBO}$, control and appraisal, subsystem, and organizational and management development.[2]

Assessment Centers, this technique was first developed in the UK and USA in 1943. An assessment center is focused on observation of behaviors across a series of selection exercises or work samples. It can be said that a central location where managers may come together to have their participation in job-related exercises evaluated by trained observers. The characteristics assessed in assessment center can be assertiveness, communicating ability, persuasive ability, planning and organizational ability, resistance to stress, self-confidence energy level, decision making, sensitivity to feelings, administrative ability, creativity, and mental alertness, etc.[10]

\section{The Content of appraisal:}

a. Quantity of work. The volume of work under normal working conditions.

b. Quality of work. It's a thoroughness, neatness, and accuracy of work Knowledge of job

c. Dependability. Conscientious, thorough, reliable, accurate, with respect to attendance, relief, lunch breaks, etc.

d. Judgement.

e. Attitude exhibits enthusiasm and cooperativeness on the job.

f. Cooperation Willingness and ability to hire others to produce desired goals.

g. Initiative.

Basically, the purpose of performance appraisal is to measure employee responsibilities and as a basis for employee improvement and development.[13]This assessment can also make employees support the smooth running of business processes and company goals. 
Besides that, performance appraisal is also used for various purposes in corporate or business organizations.

In this 4.0 era, entrepreneurship is often characterized by stiff competition in the marketplace and only entrepreneurial organizations will be able to survive.[14] Especially, organizational commitment influences employment outcomes.[15] A central concept in the domain of entrepreneurship is the Entrepreneurial orientation.[14]

\section{Conclusions}

The assessment of performance appraisalcan be known in full the quality of existing employees. This means the level of employee competence can determined, so that it can be developed to produce competitive employees. Thus, the goals of a company or business can be achieved assisted with appropriate human resource management and performance appraisal.

Performance appraisal models can be used according to the situation of the employees. Both traditional methods and modern methods, both have the same goal in its application. Therefore, as a company or business support, performance appraisal is common to do. Especially if employees have good ethics and potential, this can increase employee performance and achieve the goals of a company or business.

Acknowledgments. Committee of The First International Conference on Islamic Development Studies (ICIDS)

\section{References}

[1] D. Haluty, "Islam dan Manajemen Sumber Daya Manusia yang Berkualitas [Islam and Quality Human Resource Management]," Irfani, vol. 10, no. 1, pp. 63-74, 2014.

[2] A. Aggarwal, G. Sundar, and M. Thakur, "Techniques of Performance Appraisal - A Review," Int. J. Eng. Adv. Technol., vol. 2, no. 3, pp. 2249-8958, 2013.

[3] Z. Miftahuddin, Ibn Khaldun: Perintis Kajian Ilmu Sosial Modern. Jakarta: Dian Rakyat.

[4] A. Musa, Dialektika Islam: Etos Kerja dan Kemiskinan. Yogyakarta: Lembaga Studi Filsafat Islam, 2016.

[5] C. M. Mader, The Job Description Handbook, 3rd ed. Nolo, 2013.

[6] T. Nursofyan and U. L. Mangkurat, "Rini Rahmawati (Universitas Lambung Mangkurat) E-mail : rini,” J. Wawasan Manaj., vol. 6, no. 1, pp. 45-60, 2018.

[7] C. Barry, The Handbook of Model Job Descriptions. London: Kogan Page Publishers, 2008.

[8] E. a. Mitchell, Douglas E., Work Orientation and Job Performance: The Cultural Basis of Teaching Rewards and Incentives. Albany: State University of New York Press, 1987.

[9] E. a. Fahmi, Abu, HRD Syariah: Teori dan Implementasi. Jakarta: Gramedia Pustaka Utama, 2014.

[10] M. Khanna and R. K. Sharma, "Employees Performance Appraisal and its techniques : A Review," Asian J. Adv. Basic Sci., vol. 2, no. 2, pp. 51-58, 2014.

[11] T. Deb, Performance Appraisal and Management. Imdia: Exel Books, 2009.

[12] T. V Rao, Performance Management and Appraisal System: HR Tools for Global Competitiveness. India: SAGE Publications, 2004. 
[13] M. L. Nasrih, "Analisis Hubungan Kepuasan Kerja Terhadap Prestasi Kerja Karyawan,” Al-Iqtishad J. Islam. Econ., vol. 2, no. 1, pp. 155-180, 2016.

[14] S. Baskaran, "The Role of Work Discretion in Activating Entrepreneurial Orientation among Employees," J. Entrep. Bus., vol. 5, no. 2, pp. 11-24, 2017.

[15] L. Tien Dung, D. Phi Ho, N. Thi Kim Hiep, P. Thi Hoi, and D. Thi Phuong Hanh, "Job Satisfaction, Leadership Styles, Demographic Variables and Organisational Commitment among Pharmacists in Vietnam," South East Asian J. Manag., vol. 13, no. 1, pp. 37-52, 2019. 